\title{
EVALUATION OF RESERVOIR WATER QUALITY USING WATER QUALITY INDEX IN GOVIND BALLABH PANT SAGAR RESERVOIR, INDIA
}

\author{
Ramita Varshney* and Aarif Jamal \\ Department of Mining Engineering, Indian Institute of Technology (Banaras Hindu University), \\ Varanasi-221005, India \\ *E-mail: ramita25j@gmail.com
}

\begin{abstract}
Weighted Arithmetic Water Quality Index is a single number that expresses the water quality of a sample collected from a water body by amalgamating thirteen water quality parameters in this study. The sole of this is to express the quality of water in a simple and concise manner for recreational use such as irrigation, domestic or industrial. This paper employs Weighted Arithmetic Water Quality Index, as a simple pollution indicator tool in Govind Vallabh Pant Sagar Reservoir. The index was applied to six sampling locations and compared to each other. The quality of water was investigated for two seasons of the year i.e. pre and post-monsoon seasons. The results showed that the water quality during both the seasons was poor thereby necessitating proper treatment before it can be used for fulfilling potable requirements.
\end{abstract}

Keywords: Water Quality Index, Reservoir water, Physico-chemical parameters, Weighted Arithmetic Water Quality Index Method,

(C) RASĀYAN. All rights reserved

\section{INTRODUCTION}

Protection of surface water bodies like lakes, rivers, reservoirs plays an important role in not only providing the safe and adequate amount of water for drinking purpose but also for providing water for other purposes like irrigation, industrial use, domestic supply, etc. The surface water bodies, which are the most important sources of water for human activities are unfortunately under severe environmental stress and are being threatened as a consequence of developmental activities ${ }^{6}$. In this, reservoir water is the main source of drinking and industrial water thus having an important role in urban water systems, accounting for $90 \%$ of total urban water supply 5 .

Water pollution not only affects the quality of water but it also threats human health, economic development and social prosperity ${ }^{3}$. Therefore, it is significant to control water pollution and monitor the quality of water ${ }^{4}$. In order to assess the suitability of water for diverse uses, there is a need to employ an index that can categorize the quality of water incorporating the physic-chemical constituents of water and present them in a simple but scientifically presentable manner ${ }^{1}$. This index is known as Water Quality Index (WQI). The WQI is defined as a single numeric score that describes the surface water quality condition at a particular time and location ${ }^{2}$. Horton in 1965 developed WQI for the first time by selecting and weighting water quality parameters and introducing an aggregation function ${ }^{11}$. The WQI was then revised by the U.S. National Sanitation Foundation (NSF) using the Delphi technique. This has been widely used worldwide to assess water quality. In this study, the WQI of Gobind Ballabh Pant Sagar Reservoir has been calculated on the basis of 13 physicochemical parameters at selected sampling locations to assess the quality of water for its multifarious utilization.

\section{Study Area}

According to the 2011 census the Singrauli district has a population of about $1,178,273^{8}$ while Sonebhadra district has a population of about $1862559^{8}$ which mainly depend on adjoining reservoir i.e.

Rasayan J. Chem., 11(3), 1177-1182(2018)

http://dx.doi.org/10.31788/RJC.2018.1134023

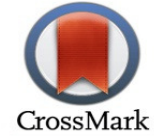


Gobind Ballabh Pant Sagar reservoir for their utility. With a catchment area of $5148 \mathrm{~km}^{2}$, it is the largest manmade reservoir of India having a storage capacity of 10.6 billion $\mathrm{m}^{3}$ was constructed in 1962 . The Rihand dam is capable of producing $300 \mathrm{MW}$ of power annually. The reservoir lies between 24 to $24^{0} 12^{\prime}$ North latitude and $82^{\circ} 38^{\prime}$ to $83^{\circ} 5^{\prime}$ East longitude. The reservoir is situated on the border of Madhya Pradesh and Uttar Pradesh and falls under 8 topographical sheets of Survey of India on 1:50,000 scale i.e. 63L/11, 63L/12, 63L/15, 63L/16, 64I/09, 64I/13, 64P/03 and 64P/04.

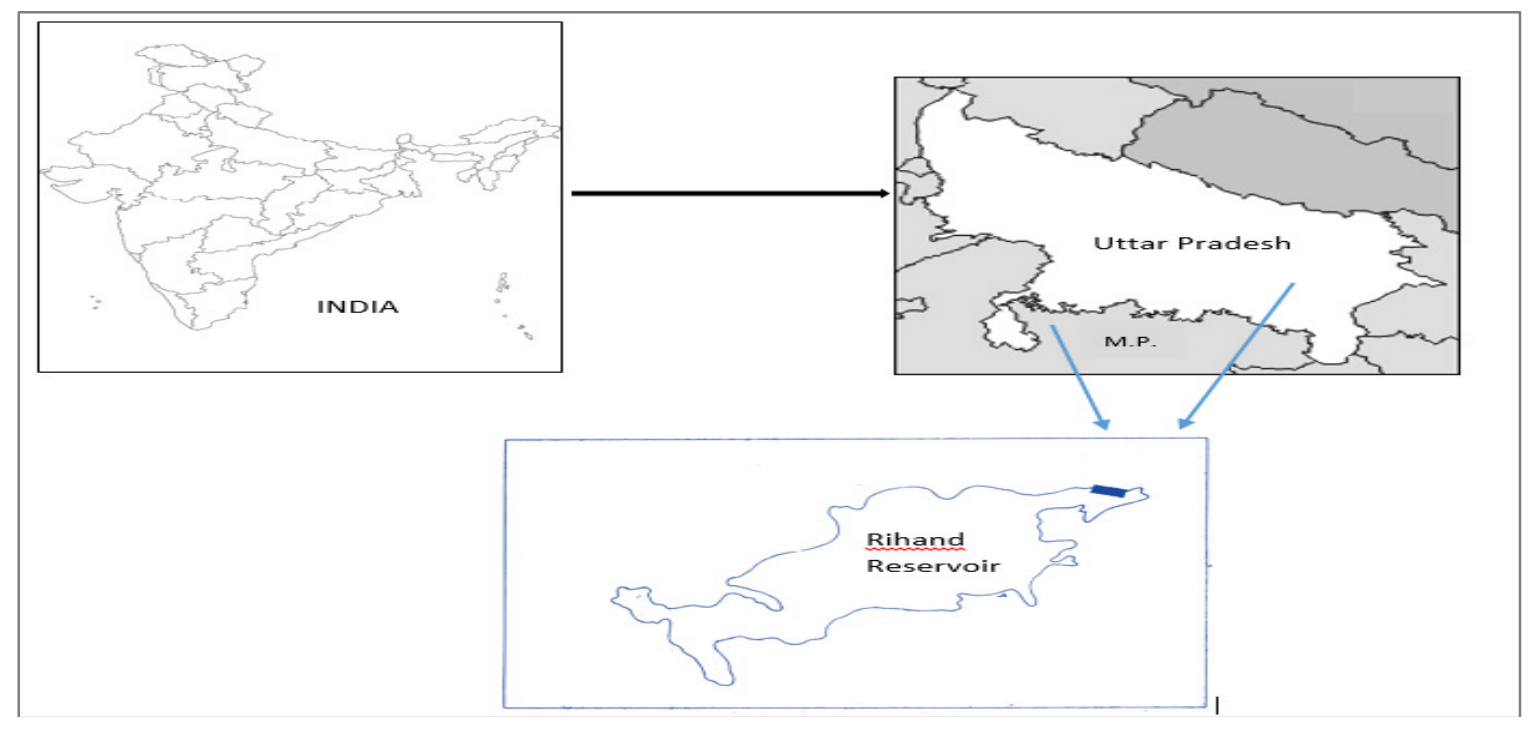

Fig.-1: Location Map of Study Area

The climate of the study area is tropical monsoonal where the temperature reaches up to $48^{0} \mathrm{C}$ during summer and falls to $6^{0} \mathrm{C}$ during winters. The construction of concrete dam called as Rihand dam was mainly done with an objective of irrigation but due to the availability of coal in nearby area the objective of the dam so as shifted into providing proper water facility to thermal power plants.

The Singrauli coalfield lies in the junctional region of East-West trending Koel-Damodar and northwestsoutheast aligned Son-Mahanadi valleys. In this, the northern limit of coalfield is characterized by EastWest trending boundary fault, which is often referred to as an offshoot of Son-Narmada lineament. In the eastern part of the coalfield, the Talchir sediment rests unconformably on the Precambarian basement whereas in the northern part, the younger lower Gondwana sediments are next against the Precambarian rocks along an east-west running fault ${ }^{9}$. The coal found in Singrauli coalfield is characterized by low volatile Bituminous variety.

\section{EXPERIMENTAL}

A field investigation was conducted properly and surface water samples were collected from six different locations around G.B. Pant Sagar reservoir. A total of twelve water samples were collected from sampling locations, six each during spring and autumn season from the same six selected locations. All the water samples were collected in clean, sterile polypropylene wide mouth reagent bottle of 1-litre capacity, brought to the laboratory and stored at $4^{\circ} \mathrm{C}$ in order to avoid any chemical alteration. The methods of sampling and collection were in accordance with Standard Methods for the Examination of Water and Wastewater (APHA 2012) ${ }^{7}$. The samples were collected between 8-11 a.m. during the first week of March and October respectively because of the presence of appropriate climatic conditions in the study area during both the seasons. pH, Electrical Conductivity (EC), Total Dissolved Solids (TDS), Dissolved Oxygen (DO) and Temperature were measured in the field using Hanna Hi 9828 multiparameter apparatus. The samples were then labeled and acidified with nitric acid to maintain at $\mathrm{pH}$ less than 2 and stored at $4^{0} \mathrm{C}$ for the analysis of other physicochemical parameters at a later stage. The number of ions of chloride, bicarbonate, calcium, magnesium, sodium, nitrate and sulphate along with hardness was 
RASĀYAN J. Chem.

Vol. 11 | No. 3 |1177 - 1182 | July - September | 2018

measured in the laboratory by using standard methodologies. References to the procedures laid down by American Public Health Association (APHA) in 'Standard Methods for the Examination of water and wastewater, $22^{\text {nd }}$ edition' were followed for the analysis of the samples collected. ${ }^{7}$ Then, for each parameter $\mathrm{Q}_{\mathrm{i}} \mathrm{W}_{\mathrm{i}}$ was calculated using the mathematical procedure given below and Weighted Arithmetic Water Quality Index formula ${ }^{10}$ was applied to calculate the WQI of selected location. The obtained values for WQI is further categorized into 5 important categories as shown in Table-1.

$\mathrm{WQI}=\sum \mathrm{Q}_{\mathrm{i}} \mathrm{W}_{\mathrm{i}} / \sum \mathrm{W}_{\mathrm{i}}$ (Weighted Arithmetic Water Quality Index formula)

$\mathrm{Q}_{\mathrm{i}}=100\left[\left(\mathrm{~V}_{\mathrm{i}}-\mathrm{V}_{0} / \mathrm{S}_{\mathrm{i}}-\mathrm{S}_{0}\right)\right]$ (Quality Rating for each parameter)

$\mathrm{W}_{\mathrm{i}}=\mathrm{K} / \mathrm{S}_{\mathrm{i}}($ Relative Weight for each parameter $)$

$\mathrm{K}=$ proportionality constant

$\mathrm{K}=1 / \sum\left(1 / \mathrm{S}_{\mathrm{i}}\right)$

$\mathrm{S}_{\mathrm{i}}=$ recommended standard value of $\mathrm{i}^{\text {th }}$ parameter.

$\mathrm{V}_{0}=$ ideal value of parameter in pure water $\mathrm{V}_{0}=0$ (except $\mathrm{pH}=7.0 \&$ D.O. $=14.6 \mathrm{mg} / \mathrm{lt}$.)

$\mathrm{V}_{\mathrm{i}}=$ estimated concentration of $\mathrm{i}^{\text {th }}$ parameter in the analyzed water.

Table-1: Water Quality Rating as per Weighted Arithmetic Water Quality Index Method ${ }^{14}$

\begin{tabular}{c|c|c|c}
\hline S. No. & WQI Value & Rating of Water Quality & Grading \\
\hline 1. & $0-25$ & Excellent Water Quality & $\mathrm{A}$ \\
\hline 2. & $25-50$ & Good Water Quality & $\mathrm{B}$ \\
\hline 3. & $51-75$ & Poor Water Quality & $\mathrm{C}$ \\
\hline 4. & $76-100$ & Very Poor Water Quality & $\mathrm{D}$ \\
\hline 5. & Above 100 & Unsuitable for drinking purpose & $\mathrm{E}$ \\
\hline
\end{tabular}

\section{RESULTS AND DISCUSSION}

The parameters used for computation of water quality in this study are selected on the basis of their direct involvement in deteriorating the quality of water for human consumption. For the calculation of Water Quality Index (WQI) during pre-monsoon and post-monsoon season, 13 water quality parameters viz:pH, Electrical Conductivity (EC), Total Dissolved Solids (TDS), Dissolved Oxygen (DO), Hardness and ions of chloride, bicarbonate, calcium, magnesium, sodium, nitrate and sulphate have been taken into consideration while the standards recommended by the World Health Organisation (WHO ${ }^{12}$ and Bureau of Indian Standards (BIS) ${ }^{13}$ for this parameter are taken into contemplation for computation of $\mathrm{q}_{\mathrm{i}}$ and $\mathrm{W}_{\mathrm{i}}$. The WQI values of the study area for both pre-monsoon and post-monsoon seasons have been calculated separately on the basis of 13 parameters for 6 sampling sites in each season.

Table-2: Physico-Chemical Characterization of Samples of Govind Ballabh Pant Sagar Reservoir during PreMonsoon Season

\begin{tabular}{|c|c|c|c|c|c|c|c|}
\hline $\begin{array}{c}\text { Sample } \\
\text { Location }\end{array} \underset{\text { Parameters }}{\downarrow}$ & Sample1 & Sample2 & Sample3 & Sample4 & Sample5 & Sample6 & $\begin{array}{l}\text { Permissible } \\
\text { limit by } \\
\text { WHO and } \\
\text { BIS }\left(\mathrm{S}_{\mathrm{i}}\right)\end{array}$ \\
\hline $\mathrm{pH}$ & 7.5 & 7.2 & 7.4 & 7.1 & 7.8 & 7.6 & $6.5-8.5$ \\
\hline $\begin{array}{c}\text { Electrical } \\
\text { Conductivity } \\
\text { (EC) }\end{array}$ & 131 & 138 & 135 & 125 & 128 & 98 & 300 \\
\hline $\begin{array}{c}\text { Total } \\
\text { Dissolved } \\
\text { Solids (TDS) }\end{array}$ & 212 & 242 & 220 & 201 & 207 & 184 & 500 \\
\hline $\begin{array}{c}\text { Total } \\
\text { Suspended } \\
\text { Solids (TSS) }\end{array}$ & 58 & 61 & 56 & 54 & 59 & 52 & 500 \\
\hline $\begin{array}{c}\text { Dissolved } \\
\text { Oxygen (DO) }\end{array}$ & 6.2 & 6.4 & 6.0 & 5.9 & 5.8 & 6.1 & $>5$ \\
\hline
\end{tabular}


RASĀYAN J. Chem.

Vol. 11 | No. 3 |1177 - 1182 | July - September | 2018

\begin{tabular}{c|c|c|c|c|c|c|c}
\hline Chloride & 169 & 130 & 143 & 126 & 170 & 162 & 250 \\
\hline Bicarbonate & 110 & 121 & 127 & 115 & 130 & 119 & 200 \\
\hline Calcium & 17 & 13 & 19 & 18 & 21 & 12 & 75 \\
\hline Magnesium & 5.28 & 4.97 & 3.53 & 3.26 & 2.82 & 2.95 & 30 \\
\hline Sulphate & 21 & 29 & 34 & 37 & 43 & 49 & 500 \\
\hline Sodium & 59 & 62 & 65 & 61 & 63 & 67 & 200 \\
\hline Nitrate & 6.8 & 7.2 & 9.1 & 8.1 & 8.3 & 7.6 & 45 \\
\hline Hardness & 64.1 & 52.9 & 62.0 & 58.4 & 64.1 & 42.1 & 300 \\
\hline
\end{tabular}

All parameters are in ppm (mg/l) except $\mathrm{pH}$ and Electrical Conductivity $(\mu \mathrm{S} / \mathrm{cm})$.

Table-3: Physico-chemical characterization of samples of Govind Ballabh Pant Sagar Reservoir during postmonsoon season

\begin{tabular}{|c|c|c|c|c|c|c|c|}
\hline $\begin{array}{c}\text { Sample } \\
\text { Location } \rightarrow \\
\text { Parameters }\end{array}$ & Sample1 & Sample2 & Sample3 & Sample4 & Sample5 & Sample6 & $\begin{array}{c}\text { Permissible } \\
\text { limit by } \\
\text { WHO and } \\
\text { BIS }\left(\mathrm{S}_{\mathrm{i}}\right) \\
\end{array}$ \\
\hline $\mathrm{pH}$ & 7.8 & 7.4 & 7.5 & 7.3 & 8.2 & 7.7 & $6.5-8.5$ \\
\hline $\begin{array}{l}\text { Electrical } \\
\text { Conductivity } \\
\text { (EC) }\end{array}$ & 165 & 177 & 173 & 181 & 162 & 169 & 300 \\
\hline $\begin{array}{c}\text { Total } \\
\text { Dissolved } \\
\text { Solids (TDS) }\end{array}$ & 316 & 346 & 324 & 298 & 307 & 274 & 500 \\
\hline $\begin{array}{c}\text { Total } \\
\text { Suspended } \\
\text { Solids (TSS) }\end{array}$ & 79 & 82 & 77 & 75 & 85 & 76 & 500 \\
\hline $\begin{array}{c}\text { Dissolved } \\
\text { Oxygen (DO) }\end{array}$ & 6.9 & 7.2 & 6.8 & 6.3 & 6.1 & 6.7 & $>5$ \\
\hline Chloride & 112 & 101 & 109 & 94 & 115 & 109 & 250 \\
\hline Bicarbonate & 126 & 133 & 139 & 129 & 142 & 130 & 200 \\
\hline Calcium & 26 & 23 & 27 & 21 & 24 & 19 & 75 \\
\hline Magnesium & 7.86 & 8.24 & 5.12 & 4.93 & 4.21 & 4.29 & 30 \\
\hline Sulphate & 18 & 21 & 28 & 31 & 36 & 39 & 500 \\
\hline Sodium & 64 & 67 & 71 & 66 & 69 & 73 & 200 \\
\hline Nitrate & 4.9 & 5.2 & 7.7 & 6.4 & 6.6 & 5.8 & 45 \\
\hline Hardness & 97.2 & 91.3 & 88.5 & 72.7 & 77.3 & 65.1 & 300 \\
\hline
\end{tabular}

All parameters are in ppm (mg/l) except $\mathrm{pH}$ and Electrical Conductivity $(\mu \mathrm{S} / \mathrm{cm})$.

Table-4: Computation of Water Quality Index (WQI) and Relative Weight $\left(\mathrm{W}_{\mathrm{i}}\right)$ for Samples during Pre-Monsoon

\begin{tabular}{|c|c|c|c|c|c|c|c|}
\hline \multicolumn{8}{|c|}{ Season with $K=2.42$} \\
\hline $\begin{array}{c}\text { Sample } \\
\text { Location with } \\
\mathrm{Q}_{\mathrm{i}} \mathrm{W}_{\mathrm{i}}\end{array}$ & Sample1 & Sample2 & Sample3 & Sample4 & Sample5 & Sample6 & $\begin{array}{c}\text { Relative } \\
\text { Weight }\left(\mathrm{W}_{\mathrm{i}}\right)\end{array}$ \\
\hline \multicolumn{8}{|l|}{ Parameters $\downarrow$} \\
\hline $\mathrm{pH}$ & 9.49 & 3.73 & 7.46 & 1.87 & 14.93 & 11.2 & 0.28 \\
\hline $\begin{array}{c}\text { Electrical } \\
\text { Conductivity } \\
\text { (EC) }\end{array}$ & 0.35 & 0.37 & 0.36 & 0.34 & 0.35 & 0.26 & 0.0081 \\
\hline $\begin{array}{c}\text { Total } \\
\text { Dissolved } \\
\text { Solids (TDS) }\end{array}$ & 0.20 & 0.23 & 0.21 & 0.19 & 0.19 & 0.18 & 0.0048 \\
\hline $\begin{array}{c}\text { Total } \\
\text { Suspended } \\
\text { Solids (TSS) }\end{array}$ & 0.055 & 0.058 & 0.054 & 0.05 & 0.057 & 0.049 & 0.0048 \\
\hline Dissolved & 42.35 & 41.34 & 43.36 & 43.86 & 44.37 & 42.85 & 0.484 \\
\hline
\end{tabular}


RASĀYAN J. Chem.

Vol. 11 | No. 3 |1177 - 1182 | July - September | 2018

\begin{tabular}{c|c|c|c|c|c|c|c}
\hline Oxygen (DO) & & & & & & & \\
\hline Chloride & 0.65 & 0.50 & 0.55 & 0.49 & 0.66 & 0.63 & 0.00968 \\
\hline Bicarbonate & 0.66 & 0.73 & 0.77 & 0.69 & 0.079 & 0.72 & 0.0121 \\
\hline Calcium & 0.73 & 0.56 & 0.82 & 0.78 & 0.90 & 0.52 & 0.0323 \\
\hline Magnesium & 1.43 & 1.34 & 0.95 & 0.88 & 0.76 & 0.79 & 0.081 \\
\hline Sulphate & 0.020 & 0.028 & 0.03 & 0.036 & 0.04 & 0.047 & 0.0121 \\
\hline Sodium & 0.36 & 0.38 & 0.39 & 0.37 & 0.38 & 0.41 & 0.054 \\
\hline Nitrate & 0.82 & 0.86 & 1.09 & 0.97 & 0.99 & 0.91 & 0.0081 \\
\hline Hardness & 0.17 & 0.14 & 0.17 & 0.16 & 0.17 & 0.11 & 0.0048 \\
\hline$\sum \mathrm{Q}_{\mathrm{i}} \mathrm{W}_{\mathrm{i}}$ & 57.30 & 50.28 & 56.23 & 50.69 & 63.89 & 58.68 & $\sum \mathrm{W}_{\mathrm{i}}=0.9956$ \\
\hline $\mathrm{WQI}$ & 57.55 & 50.50 & 56.48 & 50.91 & 64.17 & 58.94 & -- \\
\hline
\end{tabular}

The WQI values during pre-monsoon season is given in Table-4 according to which the WQI of premonsoon samples state that the status of these samples were poor ranging between 50.50 to 64.174 in which it was highest for sampling location 5 and lowest for sampling location 2 whereas the WQI of samples from post-monsoon (as stated in Table-5) too showed poor status ranging between 51.5 to 70.604 in which again the sampling location 5 showed highest and sampling location 2 showed the lowest values thereby stating that the water samples collected from the sampling sites need treatment primarily filtration and disinfection along with analysis and treatment of heavy metals if any present in reservoir water before it can be supplied for drinking or any other domestic purpose.

Table-5: Computation of Water Quality Index (WQI) and Relative Weight $\left(\mathrm{W}_{\mathrm{i}}\right)$ for Samples during Post-Monsoon Season with $\mathrm{K}=2.42$

\begin{tabular}{|c|c|c|c|c|c|c|c|}
\hline $\begin{array}{c}\underset{\text { Sample }}{\stackrel{\text { Location with }}{\longrightarrow}} \\
\mathrm{Q}_{\mathrm{i}} \mathrm{W}_{\mathrm{i}} \\
\text { Parameters }\end{array}$ & Sample1 & Sample2 & Sample3 & Sample4 & Sample5 & Sample6 & $\begin{array}{c}\text { Relative } \\
\text { Weight }\left(\mathrm{W}_{\mathrm{i}}\right)\end{array}$ \\
\hline $\mathrm{pH}$ & 14.93 & 7.47 & 9.33 & 5.6 & 22.4 & 13.07 & 0.28 \\
\hline $\begin{array}{l}\text { Electrical } \\
\text { Conductivity } \\
\text { (EC) }\end{array}$ & 0.45 & 0.48 & 0.47 & 0.49 & 0.44 & 0.46 & 0.0081 \\
\hline $\begin{array}{c}\text { Total } \\
\text { Dissolved } \\
\text { Solids (TDS) }\end{array}$ & 0.30 & 0.33 & 0.31 & 0.29 & 0.29 & 0.26 & 0.0048 \\
\hline $\begin{array}{c}\text { Total } \\
\text { Suspended } \\
\text { Solids (TSS) }\end{array}$ & 0.076 & 0.079 & 0.074 & 0.07 & 0.08 & 0.07 & 0.0048 \\
\hline $\begin{array}{c}\text { Dissolved } \\
\text { Oxygen (DO) }\end{array}$ & 38.82 & 37.31 & 39.33 & 41.85 & 42.85 & 39.83 & 0.484 \\
\hline Chloride & 0.43 & 0.39 & 0.42 & 0.36 & 0.45 & 0.42 & 0.00968 \\
\hline Bicarbonate & 0.76 & 0.81 & 0.84 & 0.78 & 0.86 & 0.79 & 0.0121 \\
\hline Calcium & 1.12 & 0.99 & 1.16 & 0.90 & 1.03 & 0.82 & 0.0323 \\
\hline Magnesium & 2.12 & 2.22 & 1.38 & 1.33 & 1.14 & 1.15 & 0.081 \\
\hline Sulphate & 0.017 & 0.02 & 0.027 & 0.029 & 0.035 & 0.037 & 0.0121 \\
\hline Sodium & 0.39 & 0.41 & 0.43 & 0.39 & 0.42 & 0.44 & 0.054 \\
\hline Nitrate & 0.59 & 0.62 & 0.92 & 0.77 & 0.095 & 0.69 & 0.0081 \\
\hline Hardness & 0.26 & 0.25 & 0.24 & 0.196 & 0.21 & 0.18 & 0.0048 \\
\hline$\sum \mathrm{Q}_{\mathrm{i}} \mathrm{W}_{\mathrm{i}}$ & 60.26 & 51.37 & 54.94 & 53.07 & 70.29 & 58.22 & $\sum \mathrm{W}_{\mathrm{i}}=0.9956$ \\
\hline WQI & 60.54 & 51.60 & 55.18 & 53.31 & 70.60 & 58.48 & -- \\
\hline
\end{tabular}

\section{CONCLUSION}

The study reveals that the Weighted Arithmetic Water Quality Index method provides a simple tool for assessment of water quality of G.B. Pant Sagar Reservoir through the samples collected from various 
sampling locations before supplying it for human consumption. The results computed above showed that the WQI of sampling sites increased during the post-monsoon season indicating that the quality of water got deteriorated during this season which may be due to the reason of addition of pollutants and sediments by natural or anthropogenic means into the reservoir during the rainy season.

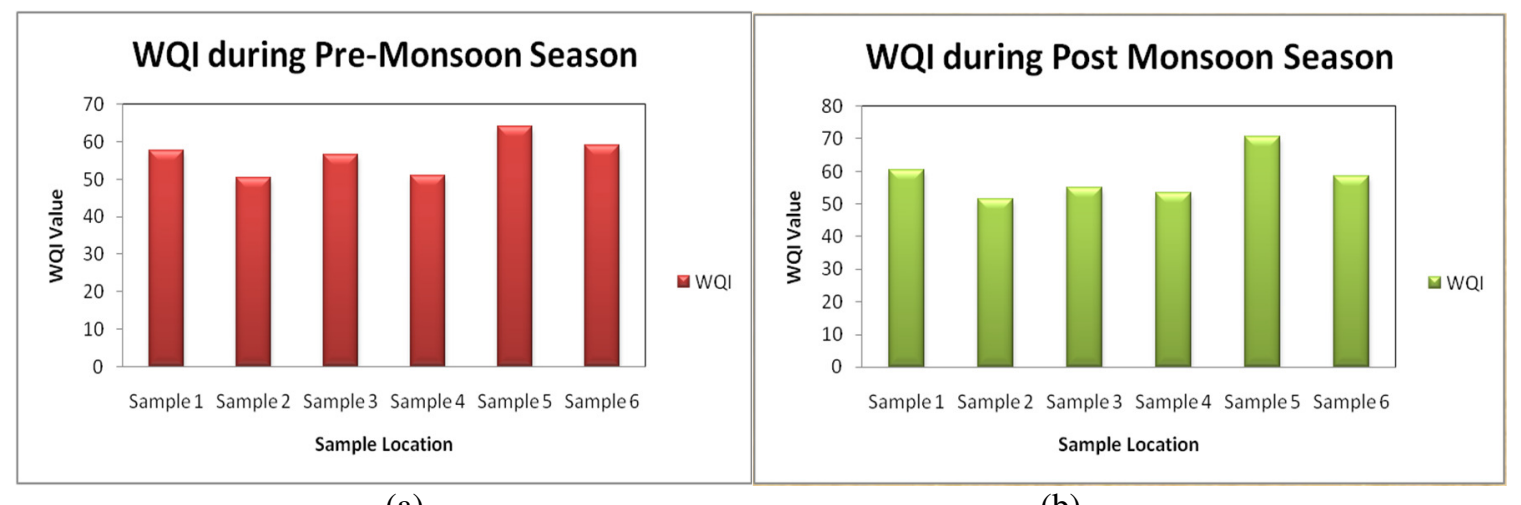

(a)

(b)

Fig.-2: Graphical Representation of WQI during (a) Pre-Monsoon and (b) Post Monsoon Season

Though, the Weighted Arithmetic Water Quality Index method is assumed to be an efficient and easy to use approach for indicating the quality of surface water bodies but still these areas require better management and implementation of mining and power plant projects to raise environmental awareness amongst the community residing nearby the affected area in order to improve the quality of water for human consumption and monitoring of its effectiveness by the local authorities.

\section{REFERENCES}

1. A. Lumb, D. Halliwell and T. Sharma, Environmental Monitoring and Assessment, 113, 429(2006), DOI: 10.1007/s10661-005-9092-6.

2. F.W. Kaurish and T. Younos, Journal of American Water Resources Association, 43(2), 545(2007), DOI: 10.1111/j.1752-1688.2007.00042.x.

3. M. Milovanovic, Desalination, 213, 173 (2007), DOI: 10.1016/j.desal.2006.06.022.

4. V. Simeonov, J.A. Stratis, C. Samara, G. Zachariadis, D. Voutsa, A. Anthemidis, WaterResearch,37, 4124 (2003), DOI: 10.1016/S0043-1354(03)00398-1.

5. W. Hou, S. Sun, M. Wang, X. Li, N. Zhang, X. Xin, L. Sun, W. Li, R.Jia, Ecological Indicators, 61, 316 (2016), DOI: 10.1016/j.ecolind.2015.09.030.

6. K. Yogendra and E.T. Puttaiah, Proceedings of Taal 2007: The 12th World Lake Conference, 346 (2008).

7. APHA (American Public Health Association), 2012, Standard methods for the examination of water and wastewater (22 ${ }^{\text {nd }}$ edition), Washington, DC: AWWA, WEF.

8. http://www.census 2011.co.in

9. R.N. Hota, P.C. Adhikari, A. Mohanty and W. Maejima, Open Journal of Geology, 2, 13 (2012), DOI: $10.4236 /$ ojg.2012.21001.

10. R.M. Brown, N.I. McClelland, R.A. Deininger and M.F. O'Connor, Indicators of Environmental Quality, 1, 182 (1972), DOI: 10.1007/978-1-4684-2856-8_15.

11. R.K. Horton, J. Water Pollu. Cont. Fed., 37(3), 305 (1965).

12. WHO, Guidelines for Drinking Water Quality, 4th Edition, 631(2017).

13. Bureau of Indian Standard, Drinking Water-Specification, Second Revision, (2012).

14. C. Chatterjee and M. Raziuddin, Nature Environment and Pollution Technology, 1(2), 189 (2002).

[RJC-4023/2018] 